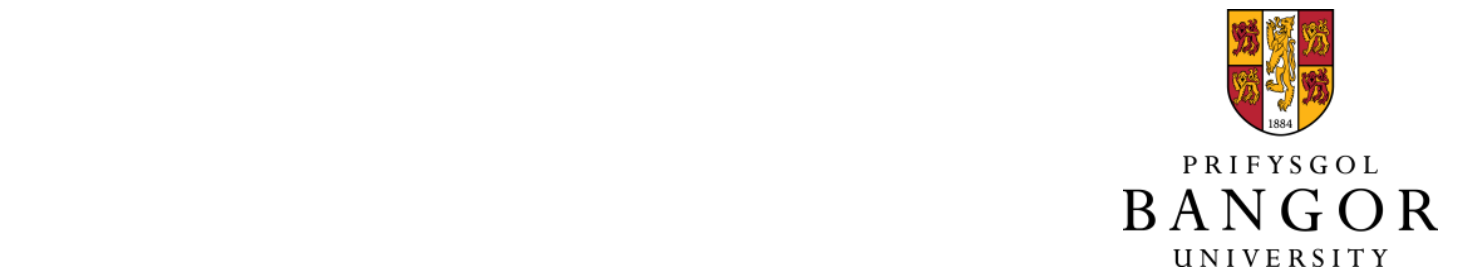

\title{
Contrasting effects of ocean warming on different components of plant- herbivore interactions
}

Pages Fauria, Jordi; Smith, Timothy M.; Tomas, Fiona; Sanmartí, Neus; Boada, Jordi; De Bari, Harriet; Pérez, Marta; Romero, Javier; Arthur, Rohan; Alcoverro, Teresa

\section{Marine Pollution Bulletin}

DOI:

10.1016/j.marpolbul.2017.10.036

Published: 01/09/2018

Peer reviewed version

Cyswllt i'r cyhoeddiad / Link to publication

Dyfyniad o'r fersiwn a gyhoeddwyd / Citation for published version (APA):

Pages Fauria, J., Smith, T. M., Tomas, F., Sanmartí, N., Boada, J., De Bari, H., Pérez, M.,

Romero, J., Arthur, R., \& Alcoverro, T. (2018). Contrasting effects of ocean warming on different components of plant-herbivore interactions. Marine Pollution Bulletin.

https://doi.org/10.1016/j.marpolbul.2017.10.036

\footnotetext{
Hawliau Cyffredinol / General rights

Copyright and moral rights for the publications made accessible in the public portal are retained by the authors and/or other copyright owners and it is a condition of accessing publications that users recognise and abide by the legal requirements associated with these rights.

- Users may download and print one copy of any publication from the public portal for the purpose of private study or research.

- You may not further distribute the material or use it for any profit-making activity or commercial gain

- You may freely distribute the URL identifying the publication in the public portal ?
}

Take down policy

If you believe that this document breaches copyright please contact us providing details, and we will remove access to the work immediately and investigate your claim. 
Jordi F. Pagès ${ }^{\mathrm{a} *}$

6

Timothy M. Smith ${ }^{\mathrm{b}, \mathrm{c}}$

7

8

$18 \quad{ }^{\mathrm{b}}$ Deakin University, Centre of Integrative Ecology, School of Life and Environmental Sciences, Geelong, Australia

$19{ }^{\mathrm{c}}$ Centre d'Estudis Avançats de Blanes (CEAB-CSIC), Accés a la cala Sant Francesc, 14, Blanes, Catalunya, Spain

${ }^{\mathrm{d} I n s t i t u t ~ M e d i t e r r a n i ~ d ' E s t u d i s ~ A v a n c ̧ a t s, ~ I M E D E A ~(C S I C-U I B), ~ M i q u e l ~ M a r q u e ̀ s ~ 21, ~ E s p o r l e s, ~ I l l e s ~ B a l e a r s, ~ S p a i n ~}$ 


\section{Abstract}

29 There is increasing uncertainty of how marine ecosystems will respond to rising

30 temperatures. While studies have focused on the impacts of warming on individual

31 species, knowledge of how species interactions are likely to respond is scant. The strength

32 of even simple two-species interactions is influenced by several interacting mechanisms,

33 each potentially changing with temperature. We used controlled experiments to assess

34 how plant-herbivore interactions respond to temperature for three structural dominant

35 macrophytes in the Mediterranean and their principal sea urchin herbivore. Increasing

36 temperature differentially influenced plant-specific growth, sea urchin growth and

37 metabolism, consumption rates and herbivore preferences, but not movement behaviour.

38 Evaluating these empirical observations against conceptual models of plant-herbivore

39 performance, it appears likely that while the strength of herbivory may increase for the

40 tested macroalga, for the two dominant seagrasses, the interaction strength may remain

41 relatively unchanged or even weaken as temperatures rise. These results show a clear set

42 of winners and losers in the warming Mediterranean as the complex factors driving

43 species interactions change.

45 Keywords

46 climate change; macroalgae; Mediterranean; seagrass; sea urchin; temperature 


\section{Highlights}

50 - Multiple mechanisms influence interactions, each likely modified by temperature.

51 - Mediterranean macrophyte-herbivore interactions show complex contrasts.

52 - Herbivory on the two main Mediterranean seagrasses is expected to decrease.

53 - A key canopy-forming macroalgae however is likely to suffer increased herbivory.

54 - Warming is creating winners and losers in temperate waters as interactions change. 


\section{Introduction}

58 Over the coming decades, the ecological impacts of global warming are expected to

59 increase as temperatures rise (IPCC, 2013). Global average sea surface temperatures are 60 predicted to rise by $0.75^{\circ} \mathrm{C}$ by 2035 (Kirtman et al., 2013) and between $1^{\circ} \mathrm{C}$ and more than

$61 \quad 3^{\circ} \mathrm{C}$ by 2100 (Collins et al., 2013), relative to the reference period 1986-2005. While a

62 large body of research has focused on the direct effects of global change on population 63 abundances, community composition, and organismal physiology (e.g. Sala et al., 2000), 64 global change may cause less obvious alterations to the networks of interactions among species (Tylianakis et al., 2008). Indeed, biotic interactions such as predation, herbivory, parasitism or mutualism are key in maintaining ecosystems' biodiversity, resilience and services (Bascompte et al., 2006; Dobson et al., 2011; Ives and Carpenter, 2007). The historical lack of research on the effects of warming on biotic interactions, especially in marine ecosystems (Wernberg et al. 2012, but see recent advances, e.g. Gutow et al., 2016; Hernán et al., 2017), likely stems from difficulties in quantifying modifications in interactions compared to documenting changes in single species abundance, biodiversity or individual physiological processes (McCann, 2007; Somero, 2012; Wernberg et al., 2012). Even a simple two-species interaction is ridden with complexities, driven by a host of biological, behavioural and ecological mechanisms that can all interact in often surprising ways (Boada et al., 2017). Unravelling these mechanisms and understanding how they are likely to respond to change is far from trivial. Indeed, interactions may be particularly susceptible to warming, since they are sensitive to the relative abundances of the set of interacting species, their physiology, phenology and behaviour (Parmesan, 2006; Suttle et al., 2007; Tylianakis et al., 2007). 
81 The interaction between a primary producer and its consumer can be used as a basic model to explore the complexity inherent in understanding the effects of changing temperatures at the community level. Plant-herbivore interactions are crucial for the evolution of both plant and herbivore traits (e.g. Fritz and Simms, 1992), and are critical in determining the abundance of primary producers globally (Cebrián, 1999). They structure both terrestrial and marine food webs and ultimately determine whether the world is dominated by producers or consumers (Polis, 1999). Plant-herbivore interactions play a central role in driving marine ecosystem dynamics (e.g. Bakker et al., 2016), and it is far from clear how the strength of these interactions will respond to a changing 90 climate.

92 For a start, trophic interactions are regulated by the autoecology of the intervening species.

93 Temperature can alter plant and animal growth and survival rates, which influence their 94 population abundance, playing a crucial role in determining trophic interactions (Bale et 95 al., 2002; O’Connor, 2009; Post and Pedersen, 2008). In addition, nonlethal temperature 96 rises tend to increase growth and production of plants (Nemani et al., 2003; Post and 97 Pedersen, 2008; Way and Oren, 2010), given that biochemical reaction rates accelerate with temperature fuelled by an increase in kinetic energy (Janssens et al., 2015). Similarly, moderate warming will also likely result in increased growth rates of ectothermic animals

100 (Kordas et al., 2011), decreased development time, increased herbivore population sizes 101 and expanded geographic ranges (Bale et al., 2002; O'Connor et al., 2011). Moreover, 102 both animal and plant respiration rates show higher thermal sensitivity compared to 103 photosynthetic rates (Allen et al., 2005; Padilla-Gamiño and Carpenter, 2007). In addition, 104 higher temperatures may also imply changes in animal behaviour, such as faster and 105 longer animal movements and also increased feeding rates as metabolic needs increase 
106 (Gibert et al., 2016; Kordas et al., 2011). This raises the question whether warming will 107 expand the spatial scale over which key species exert their influence (Welsh and

108 Bellwood, 2012). In addition, movement patterns have been linked to the feeding 109 capacity of some animals, with individuals that display restricted mobility having a lower 110 impact on their resources (Hereu, 2005).

112 Plants respond to herbivory using a range of strategies. While some plants are well-

113 adapted to tolerate herbivory pressure (Strauss and Agrawal, 1999), herbivory often

114 triggers compensatory growth (Sanmartí et al., 2014; Vergés et al., 2008), or an increase

115 in deterrent secondary metabolites (Tomas et al., 2015; Vergés et al., 2007a), thus

116 influencing herbivore feeding choices. How each of these individual mechanisms will

117 work together to influence the overall outcome of plant-herbivore interactions in a

118 warming environment is an open question (Post and Pedersen, 2008). For a start, it would

119 help to understand how the different mechanisms influencing the strength of the 120 interaction respond to warming. Synthesizing these responses could give us a better sense 121 of how plant-herbivore interaction strength is likely to change as temperatures increase.

123 As a simple heuristic, we propose a model to assess how warming is likely to change the 124 impacts of herbivory on vegetation. At its simplest, it is possible to conceive three 125 potential responses derived from the interplay between the individual responses of plant 126 and herbivores to warming (see Fig. 1 and see Supplementary Material): (i) if plant and 127 herbivores respond equally to warming (in terms of individual growth, termed 128 "performance" for the sake of simplicity), herbivore pressure will remain unchanged (Fig. 129 1a); (ii) if the plant's optimal performance range extends to higher temperatures than the 130 herbivore's performance range, then herbivore pressure will decrease (Fig. 1b); (iii) and 
131 if the optimum temperature for plant performance is lower than that of the herbivore, then

132 herbivore pressure will increase with warming (Fig. 1c). We define herbivore pressure as

133 the fraction of primary production removed by an individual herbivore - obtained by

134 dividing herbivore performance by plant performance.

135

136 Our study aims to explore which of the many factors that could potentially influence

137 plant-herbivore interactions are likely to change given projected temperature scenarios in

138 three important Mediterranean macrophytes and their sea urchin common consumer. We

139 focus on plant growth, herbivore growth and respiration, and herbivore behaviour

140 (movement patterns, feeding choices and rates). We integrate these responses and

141 compare them to the heuristic models presented above, to assess how the strength of

142 herbivory is likely to shift as temperatures increase depending on plant species identity

143 and characteristics. As an enclosed temperate sea, the Mediterranean is experiencing

144 rapid temperature change (Coma et al., 2009; Garrabou et al., 2009) but we know very

145 little of how herbivory processes are likely to be affected in these waters. We aim to fill

146 this gap.

$148 \quad$ Materials and Methods

149 Study system

150 Our study focuses on the subtidal photophilic environments of the Mediterranean,

151 examining interactions between the main invertebrate herbivore in these systems and the

152 principal canopy-forming macrophyte species in sandy and rocky bottoms. Sandy areas

153 are typically dominated by the seagrasses Posidonia oceanica (L.) Delile and Cymodocea

154 nodosa (Ucria) Ascherson, while rocky areas are dominated by macroalgal communities

155 (largely Cystoseira mediterranea (Sauvageau)). These primary producers are all 
156 consumed by the sea urchin Paracentrotus lividus (Lam.), which is the most important

157 invertebrate herbivore in the Mediterranean (Boudouresque and Verlaque, 2001).

158

159 P. oceanica is a stenohaline seagrass species with high thermal sensitivity (Gacia et al.,

160 2007; Tomasello et al., 2009); shoot mortality is known to increase by $2 \%$ year $^{-1}$ for each

161 additional degree of annual maximum temperature (Marbà and Duarte, 2010), with some

162 studies arguing it might become functionally extinct in the Mediterranean during this

163 century as a result of warming (Jorda et al., 2012). C. nodosa is the second most abundant

164 seagrass species occupying soft bottoms, and occurs mostly in coastal lagoons and

165 sheltered bays, where it can endure a wide range of temperatures and salinities (Pagès et

166 al., 2010; Pérez and Romero, 1992). Rocky littoral and infralittoral environments are

167 dominated by a diverse assemblage of canopy-forming macroalgae, of which $C$.

168 mediterranea is among the most dominant (Ballesteros, 1992). To our knowledge, little

169 is known of its response to warming. The sea urchin, P.lividus is a key herbivore both in

170 algal-dominated rocky bottoms, where it can produce barren overgrazed areas (e.g. Boada

171 et al., 2017), and in seagrass meadows, where it can consume up to $20 \%$ of annual

172 seagrass production (Prado et al., 2007; Tomas et al., 2005). In addition, in the presence

173 of predators, $P$. lividus shows very restricted movements, and when released from

174 predation pressure, browses much more extensively, which can have important

175 consequences for the plant resources they feed on (Hereu, 2005). Despite its ecological

176 importance, the response of this sea urchin species to warming is not clear, with adult

177 skeletons remaining unaffected by warming (Collard et al., 2016), while larval fitness

178 being reduced at high temperatures (García et al., 2015).

179

$180 \quad$ Study design 
181 We conducted a series of modular laboratory experiments to explore the influence of 182 temperature on different components of the interaction between macrophytes and

183 herbivorous sea urchins. This included testing the effects of temperature on plant growth,

184 sea urchin growth and respiration, movement behaviour, plant consumption and plant

185 choice. The results of these controlled experiments were used to inform empirical

186 performance curves for the three dominant macrophyte species and their principal 187 invertebrate herbivore. We used these empirical performance curves to evaluate the 188 direction plant-urchin interactions will likely take as temperatures increase for each of 189 the studied plant species. We used different temperature conditions that aimed at 190 capturing current mean and maximum summer temperatures present in the NW

191 Mediterranean plus potential extremely warm temperatures. The analysis of the longest

192 data series available for sea surface temperature in the Catalan coast (l'Estartit, 1975-

193 present, data provided by J. Pascual) shows that the mean summer sea surface temperature

194 is $22^{\circ} \mathrm{C}$, with maximum temperatures in August being $23.8^{\circ} \mathrm{C}$ on average and with

195 temperatures above $28^{\circ} \mathrm{C}$ being extremely rare (J. Pascual unpublished data, Garrabou et

196 al., 2009). Using these known ranges, we determined the different temperature treatments

197 for each of the manipulative experiments described below.

199 All the urchins, C. mediterranea, and P. oceanica samples used in the manipulative 200 experiments were collected near Blanes $\left(41^{\circ} 40^{\prime} \mathrm{N}, 2^{\circ} 48^{\prime} \mathrm{E}\right)$. C. nodosa samples were 201 collected in a bay in the Ebre delta $\left(40^{\circ} 35^{\prime} \mathrm{N}, 0^{\circ} 37^{\prime} \mathrm{E}\right)$. To minimise inter-seasonal 202 influences all the sampling was done in spring or early summer between 2014 and 2016 203 depending on the experiment (the average SST at that time is $13-16^{\circ} \mathrm{C}$ ). Water 204 temperature treatments in all of the aquaria were achieved by increasing or decreasing 
water temperatures by $1^{\circ} \mathrm{C}$ every 6 hours until treatment temperatures were reached, to prevent plants or animals from suffering a thermic shock.

207

\section{Plant growth}

209 The effect of increasing temperature on plant growth was assessed by determining either

210 leaf elongation or biomass change in each of the three plant species under different 211 temperature conditions. We collected 30 P. oceanica shoots in the field and placed them

212 in 6 aerated flow-through $200 \mathrm{~L}$ aquaria within an hour (5 shoots per aquarium). We

213 randomly assigned each aquarium to two growing temperature treatments $\left(18^{\circ} \mathrm{C}\right.$ or $\left.25^{\circ} \mathrm{C}\right)$.

214 Aquaria were placed in full sunlight and the shoots were weighted down to ensure they

215 remained submerged. All shoots were marked near the ligula with a needle to assess leaf 216 elongation over 15 days (modified Zieman method, see e.g. Pérez and Romero, 1994). A

217 similar procedure was used for C. nodosa seagrass shoots. 45 shoots were harvested from

218 the field and placed in 9 aquaria (5 shoots per aquarium). We randomly assigned each

219 aquarium to 3 temperature treatments $\left(20,30,35^{\circ} \mathrm{C}\right)$. Again, all shoots were marked near 220 the ligula with a needle to assess leaf elongation over 15 days as described above. Note 221 that we used higher temperature treatments for C. nodosa, given this species lives in shallower, often enclosed bays. Finally, for $C$. mediterranea, we collected 10 thalli and randomly allocated each of them to one of two aerated flow-through temperature

224 treatment aquaria $\left(18^{\circ} \mathrm{C}\right.$ or $\left.25^{\circ} \mathrm{C}\right)(5$ thalli per treatment $) .200 \mathrm{~L}$ aquaria were placed in 225 full sunlight and the thalli were weighted down to ensure they remained submerged.

226 Growth of $C$. mediterranea, was estimated as the change in biomass (as fresh weight, $\mathrm{g}$ ) 227 of each alga from the start to the end of the experiment ( 5 weeks). Even if all thalli from 228 the same treatment were placed in the same aquarium, aquaria were big enough $(200 \mathrm{~L})$ 
to allow sufficiently spatial heterogeneity (i.e. differences in temperature of $0.2^{\circ} \mathrm{C}$ ) to

230 avoid pseudoreplication (Hurlbert, 1984).

231

232 Plant growth data was analysed in $\mathrm{R}$ with linear models containing the response variable

233 'plant growth' and the predictor variable 'temperature' coded as a fixed factor with 2

234 levels for P. oceanica and C. Mediterranea, and with 3 levels for C. nodosa. We tested if 235 the random grouping variable 'aquarium' should be added to the linear models, but

236 Akaike Information Criterion (AIC) and Log Likelihood Ratio recommended dropping 237 random effects (Zuur et al., 2009) from all the models except for the analysis of C. nodosa 238 growth. Assumptions of normality and homoscedasticity were checked graphically and 239 fulfilled in all cases (in the case of C. nodosa growth, data was square root transformed).

\section{Herbivore growth and respiration}

242 The effect of temperature on sea urchin growth was assessed by comparing the growth of 243 urchins at different water temperatures. Sea urchins of different sizes were collected in 244 the field, randomly allocated to different aquaria for each temperature treatment $(16,19$, $24522,25,28$ and $31{ }^{\circ} \mathrm{C}$ treatments, 6 aquaria per treatment) and fed ad libitum a mix of 246 algae every three days, for the entire duration of the experiment. Each aquarium had two 247 small $(<3 \mathrm{~cm})$, two medium $(3-5 \mathrm{~cm})$ and two large $(>5 \mathrm{~cm})$ individuals. We 248 photographed all individuals from each aquarium and temperature treatment at the start 249 of the experiment (216 individuals) and after two months $(<200)$. Some individuals did 250 not survive for the entire duration of the experiment and were excluded from the analyses. 251 Images were taken with the aboral side of each individual facing upwards and with a ruler 252 as measure reference. We used imageJ to estimate urchin test diameter to the nearest 
millimetre. Growth was calculated as the increase in test diameter of each individual sea urchin from the start to the end of the experiment.

256 The effect of temperature on sea urchin respiration was assessed by comparing oxygen 257 concentration before and after a 90-minute incubation of three replicate individuals per 258 temperature treatment $\left(16,19,22,25\right.$ and $\left.28^{\circ} \mathrm{C}\right)$ and for three different sea urchin sizes 259 (small $[<3 \mathrm{~cm}]$, medium [3-5 cm], large [ $>5 \mathrm{~cm}]$ ), placed in hermetic 1L glass containers.

260 Sea urchins were collected from the field and fed ad libitum a mix of algae for the entire 261 duration of the experiment. An incubation time of 90 minutes was determined in pilot 262 studies to assess the kinetics of decline in dissolved oxygen levels in the container.

263 Oxygen concentration $(\mathrm{mg} / \mathrm{l})$ was measured at the start and the end of the experimental 264 period with an optical dissolved oxygen meter (YSI, ProOBOD) placed inside the container. Sensor calibration and salinity corrections were done following manual instructions. Oxygen saturations below $80 \%$ were not observed in the trials. Shaking avoided temperature and oxygen gradients developing within the container during measurements. Oxygen consumption was calculated following the equation:

$$
\text { Oxygen consumption }\left(\mathrm{mg} \mathrm{ind}^{-1} \mathrm{~h}^{-1}\right)=\left[\left(\mathrm{O}_{0}-\mathrm{O}_{\mathrm{t}}\right) * \mathrm{~V} / \mathrm{T}\right]
$$

270 Where $\mathrm{O}_{\mathrm{o}}$ and $\mathrm{O}_{\mathrm{t}}$ are the initial and final oxygen concentrations $\left(\mathrm{mg} \mathrm{O}_{2} \mathrm{l}^{-1}\right)$ measured, $\mathrm{T}$

271 is the incubation time (h) and $\mathrm{V}$ is the volume (l) of the container.

273 The response variables 'sea urchin growth' and 'sea urchin respiration' were analysed in

$274 \mathrm{R}$ with linear models. Given that in this case we had 5-6 levels of the predictor variable temperature, we treated it as a continuous variable instead of a factor. This allowed us to test not only the linear effect of temperature on growth and respiration rates, but also the 
quadratic term. Sea urchin size was used as a covariate. Assumptions of normality and homoscedasticity were checked graphically and fulfilled in both cases.

\section{Herbivore movement behaviour}

281 A separate laboratory experiment was performed to assess the effect of temperature on $P$.

282 lividus movement patterns. Sea urchins of a similar size (between 2-3 cm) were collected and placed in large aquaria with seawater either at $18^{\circ} \mathrm{C}$ or at $25^{\circ} \mathrm{C}$ for acclimation, and fed a mix of $P$. oceanica leaves and macroalgae. To test their movement patterns at different temperatures, we placed urchins in 1-metre circular tanks (void of food) either at $18^{\circ} \mathrm{C}(\mathrm{n}=21)$ or $25^{\circ} \mathrm{C}(\mathrm{n}=14)$. Each sea urchin was tested only once and urchins were transferred from the acclimating aquaria to tanks of the same temperature. The arenas were lit with fluorescent light sources and urchin movements were recorded using stopmotion filming (one image taken every 30 seconds) from above. Urchins were placed at the centre of the arena at the beginning of each trial and their movement was tracked until they reached $10 \mathrm{~cm}$ from the edge of the tank. The tank was emptied, and carefully cleaned at the end of each day of tests to ensure that cues from the previous trial did not influence subsequent trials (e.g. Yerramilli and Johnsen, 2010).

295 The movement response of sea urchins to warming was determined by analysing a total of 3292 images that resulted from the experiment. The $\mathrm{x}$ and $\mathrm{y}$ coordinates of each urchin were obtained using an image processing toolbox in Matlab (Mathworks Ltd) and then analysed with the adehabitatLT package in R (Calenge, 2011). This package computes the increments in the $\mathrm{x}$ and $\mathrm{y}$ axis for each step of the trajectory (time interval $=30$ seconds). The $\mathrm{x}$ and $\mathrm{y}$ coordinates of each individual trajectory were used to assess the movement behaviour of sea urchins in each condition. We used a general numerical 
302 approach based on the analysis of the $\mathrm{q}^{\text {th }}$ order long-range correlations in sea urchin 303 displacements (for more information see Supplementary Information and Seuront and 304 Stanley, 2014).

305

306 Finally, for each replicate sea urchin we calculated the mean sea urchin speed and the 307 straightness index. The straightness index (Is), a measure of path tortuosity, is a 308 dimensionless number that ranges from 1 (maximum straightness) to 0 (maximum 309 tortuosity). It is the ratio of the Euclidian distance between the initial and final point of

310 the trajectory, and the sum of Euclidian distances between pairs of points separated by a

311 given time. Since different windows of time result in different Is (Benhamou 2004), we

312 calculated this index for a range of window widths. Comparisons between experiments 313 were consistent regardless of window width and, we only present the Is for a window of 3141 step (30 seconds).

316 The significance of the differences between the empirical values of the function $\zeta(q)$ was 317 analysed with a linear model, considering as a response variable the slope of the 318 exponents of the $\mathrm{q}^{\text {th }}$ order moments $(\zeta(\mathrm{q}))$ ' and the fixed factor 'temperature' (2 levels: $31918^{\circ} \mathrm{C}$ and $25^{\circ} \mathrm{C}$ ) as the predictor. Each individual sea urchin was considered a replicate.

320 The response variables mean sea urchin speed and tortuosity were analysed with a linear 321 model to assess the effects of the predictor temperature (fixed factor, 2 levels). Normality 322 and homoscedasticity were assessed graphically and fulfilled in all cases.

Herbivore consumption

325 The effect of temperature on consumption was assessed by comparing the amount of 326 seagrass $P$. oceanica, $C$. nodosa and algae $C$. mediterranea eaten by the urchin $P$. lividus 
327 at different water temperatures in separate experiments. In each experiment, $200 \mathrm{~L}$ 328 aquaria were divided into 6 compartments, 5 of which contained a sea urchin with plant

329 biomass and the $6^{\text {th }}$ compartment was maintained as control, with only plant material to 330 account for plant losses not due to consumption by sea urchins. Two aquaria were 331 allocated to one of 3 treatments in experiments using C. nodosa and P.oceanica , 15, 20 332 or $25^{\circ} \mathrm{C}$ and 4 treatments for C. mediterranea, $15,22,25$ or $28^{\circ} \mathrm{C}$. Urchins were starved 333 for 3 days before a known amount of plant material was placed in each compartment. 334 After 2-8 days (depending on the plant species) all remaining plant material in each 335 compartment was removed and weighed to estimate the biomass eaten. This was repeated 336 twice for $P$. oceanica and $C$. Mediterranea, and three times for $C$. nodosa. While the 337 possibility of changes in plant palatability in the course of the feeding experiment cannot 338 be ruled out, we think it very unlikely given the short duration of our feeding trials compared to the rate of change in plant metabolites and toughness (i.e. in the order of

340 weeks to months, Hernán et al., 2017).

342 The effects of the fixed factor 'temperature' (3 levels: $\left.15,20,25^{\circ} \mathrm{C}\right)$ on the response 343 variable 'sea urchin consumption' of the seagrass $P$. oceanica was analysed with a 344 generalised linear mixed effects model with a Poisson distribution, due to the high number 345 of zeros of the response variable. 'Sea urchin consumption' was the result of subtracting 346 the initial plant biomass by the final biomass in each compartment and corrected by 347 subtracting any autogenic change (estimated from the biomass change in control 348 compartments). We used the function glmer from the package lme4 (Bates et al., 2017).

349 The random effect 'aquarium' could not be dropped from the model according to the 350 Akaike Information Criterion (AIC) and the Log Likelihood Ratio (Zuur et al., 2009). We 351 used a similar generalised linear model to assess the effect of the fixed factor 'temperature' 
352 (3 levels: $\left.15,20,25^{\circ} \mathrm{C}\right)$ on the consumption of $C$. nodosa. However, in this case we used 353 a negative binomial distribution due to the response variable being overdispersed (Zuur 354 et al., 2009). Again, we could not drop the random effect 'aquarium' according to AIC 355 and the Log Likelihood Ratio. Finally, to analyse the effects of temperature on the 356 consumption of $C$. mediterranea, we used a simple linear model. Assumptions of 357 normality and homoscedasticity were checked graphically and fulfilled in all cases.

\section{Herbivore choice experiments}

360 An herbivore choice experiment was undertaken to determine if changes in water 361 temperature affected plant defence mechanisms. Shoots of the seagrasses P. oceanica and

362 C. nodosa were collected and stored in either $22^{\circ} \mathrm{C}$ or $30^{\circ} \mathrm{C}$ treatment aquaria for 3 weeks 363 to allow changes to plant metabolites. Seagrass traits generally respond within these time 364 frames to changes in environmental conditions (Hernán et al., 2017, 2016; Jordi F Pagès et al., 2010; Ruiz et al., 2001). The alga C. mediterranea was collected and stored in aquaria at $18^{\circ} \mathrm{C}$ and $25^{\circ} \mathrm{C}$, since thalli could not survive the $30^{\circ} \mathrm{C}$ treatment. Experiments

367 were conducted by placing $20 \mathrm{~cm}$ of seagrass or $1 \mathrm{~g}$ of algae from each temperature treatment at either end of $5 \mathrm{~L}$ aquaria containing an urchin and ambient flow through water. This was done for 36 aquaria containing $P$. oceanica treatments, 23 containing $C$. nodosa incubated at 22 and $30^{\circ} \mathrm{C}$ treatments and 25 aquaria containing $C$. mediterranea

371 incubated at 15 and $25^{\circ} \mathrm{C}$ treatments. Seagrass and algae were measured or weighed to 372 determine the amount consumed by urchin after half of all the plant material in each 373 aquarium had been eaten or 10 days had elapsed. Each aquarium was treated as a replicate 374 but aquaria where no plants were eaten after 10 days were removed from the analysis.

375 For each plant species 5 aquaria containing plant material but no urchins were used as 376 controls for autogenic change. However, we did not need to correct for any autogenic 
377 change, given that there was no difference in length or weight of plant material in any of 378 the controls at the end of each experiment.

380 To assess if there was a preference for plants incubated at each temperature treatment, we

381 calculated the difference between consumption at lower and higher temperature

382 treatments. We then checked the normality of these differences and applied a T-test or a

383 Wilcoxon rank test depending on whether normality was fulfilled or not respectively.

384 Both statistical analyses test whether the vector of differences in consumption are 385 significantly different from zero (alpha $=0.05)$. A significant difference indicates a 386 preferred choice.

Plant performance, herbivore performance and herbivore pressure conceptual curves

389 In order to model both plants' and urchins' thermal performance curves, we used 390 modified Gaussian functions obtained from Angilletta (2006). We parameterised each

391 function with values chosen to best reflect the empirical optima observed in our 392 experiments (using data from Fig. 2 for the plants, and from Fig. 3 and 4 for the

393 herbivores). These parameter values do not bear biological meaning, but were used to 394 observe the shape of the resulting curves (see supplementary information), using the web 395 app Geogebra (www.geogebra.org). For the herbivorous sea urchins, we modelled two 396 types of performance curves depending on whether sea urchin feeding preferences were 397 influenced by the incubation temperature of their feeding source (see supplementary 398 information): a continuous modified Gaussian function was used when sea urchins did 399 not modify their preference when offered plants incubated at warm temperatures; while a 400 stepwise function was used to impose a truncation of the thermal performance curves of 401 sea urchins, to mimic the effect of offering them plants incubated at warm temperatures 
402 (i.e. less preferred). The stepwise function behaves as a modified Gaussian for $\mathrm{x}<2$, but

403 otherwise it quickly drops to 0 (and then negative values, with no biological meaning in

404 this case). Finally, to obtain the herbivore pressure curve, we divided the thermal

405 performance function of sea urchins by the thermal performance function of each plant

406 (see supplementary).

407

408 Results

409 Plant Growth

410 Temperature significantly affected the growth rates of the three plants studied. $P$.

411 oceanica and $C$. mediterranea displayed significantly lower growth rates at warmer

412 temperatures $\left(25\right.$ vs $18^{\circ} \mathrm{C}$; Fig. 2a,c, Table 1). In contrast, C. nodosa displayed higher

413 growth rates at temperatures as high as $30^{\circ} \mathrm{C}$, compared to cooler and warmer treatments

414 (20 and $\left.35^{\circ} \mathrm{C}\right)$ (Fig. 2b, Table 1).

415

416 Herbivore growth and respiration

417 Temperature significantly affected both the growth and respiration of the herbivorous sea

418 urchin P. lividus (Fig. 3, Table 1). The best model fitting our data included the quadratic

419 term of temperature, highlighting a temperature that maximises both processes at ca. $22^{\circ} \mathrm{C}$.

420 Sea urchin size also significantly affected both growth and respiration rates (see 421 supplementary Fig. S1a,b).

422

423 Herbivore behaviour

424 Sea urchin movement patterns in the lab did not change significantly between temperature 425 treatments. Their trajectories were similar in terms of tortuosity (Fig. 4a), and long range 426 correlations (Fig. 4c). There was a faint trend of slower velocities at warmer temperatures 
427 (Fig. 4b), but this was not significant at $\alpha=0.05$. As is typical for this species (Pagès,

428 2013) their trajectories were in the realm of superdiffusive movements, nearer to ballistic 429 than Brownian motion (Fig. 4c).

430

431 Herbivore consumption and feeding choice experiments

432 Sea urchin feeding rates on both seagrass species were maintained from 15 to $20^{\circ} \mathrm{C}$, but 433 then plunged at the warmest treatment $\left(25^{\circ} \mathrm{C}\right)$ (Fig. 5a,c, Table 1). Moreover, for both 434 seagrass species, sea urchins preferred seagrass leaves that had been incubated at cooler 435 temperatures (Fig. 5b,d, Table 1). In contrast, sea urchin feeding rates on the alga $C$. 436 mediterranea were sustained even at higher temperatures, although with a negative trend 437 towards the warmest treatments (Fig. 5e, Table 1). Sea urchins did not display any 438 preferences between algae incubated at cool or warm treatments (Fig. 5f).

\section{Discussion}

441 Increasing temperatures are likely to trigger a complex suite of responses in the dynamics 442 of plant-herbivore interactions, with potentially far-reaching consequences for 443 Mediterranean macrophyte communities. While it is clear that some plant species, like

444 Posidonia oceanica and Cystoseira mediterranea will be pushed beyond their optima and

445 show decreased growth, Cymodocea nodosa may actually benefit due to its high thermal 446 optimum. Together with the other responses to temperature evidenced here, which 447 include sea urchin growth, respiration, feeding rates and plant susceptibility to 448 consumption, it appears that while the strength of the plant-sea urchin interaction may 449 weaken for seagrass species - quite considerably in the case of $C$. nodosa - herbivory 450 pressure may actually increase on the macroalga (see these results using the framework of our heuristic models in Fig. 6). 
453 As plant-herbivore interactions are the outcome of several processes acting together, 454 changes in any one of these processes could influence the interaction. The picture further 455 gains in complexity because as found elsewhere (Sentis et al., 2015; Van De Velde et al., 456 2016), not all processes are equally influenced by temperature. While growth and feeding 457 showed clear directional responses, plant susceptibility to being consumed exhibited 458 contrasting responses, and urchin movement did not change. In addition, these responses 459 were highly species specific, dependent on the inherent tolerance limits of each species 460 (Kordas et al., 2011). Thus, while both $P$. oceanica and C. mediterranea showed higher 461 growth at lower temperatures (as is typical for most temperate species, Lee et al., 2007),

462 C. nodosa grew best at $30^{\circ} \mathrm{C}$. The responses of their common sea urchin consumer to 463 increasing temperatures varied. Surprisingly, while growth and respiration were highest 464 at intermediate temperatures (ca. $22^{\circ} \mathrm{C}$, see Fig. 3), P. lividus did not modify its movement 465 behaviour with increasing temperatures. Consumption rates did not correspond well with 466 urchin growth either; at $25^{\circ} \mathrm{C}$, urchins had practically stopped eating. Mismatches 467 between consumption and metabolism/growth are common in many species including 468 urchins, likely representing physiological limits to plasticity (Lemoine and Burkepile, 469 2012). In addition, while the palatability of the two seagrass species apparently declined 470 (possibly as a result of increased production of secondary compounds (Vergés et al., 471 2007b), but see Hernán et al., 2017), this was not true for the macrophyte $C$. 472 mediterranea. These differences can lead to differential susceptibilities of species to 473 herbivory pressure across the seascape as temperature increases (Peñuelas and Staudt, 474 2010; Poore et al., 2013). 
476 Global warming is changing the odds for Mediterranean macrophytes by creating clear

477 'winners' and 'losers' among the species that dominate these waters at present. What is

478 interesting, though, is that these patterns arise not as a result of a single mechanism or

479 process that changes with temperature, but because of the interplay between several

480 mechanisms that together shape the plant-herbivore interaction. Thus, the expected

481 decrease in herbivory pressure with temperature for C. nodosa (see Fig. 6b), results not

482 merely from a faster growth, and thus increased productivity, but also because it reduces

483 its palatability to urchins (Figs. 5d) and because sea urchins consume much less at higher

484 temperatures (Fig. 5c, independent of seagrass palatability). Consequently, C. nodosa is

485 likely to be released from herbivory pressure as temperatures increase (Fig. 6b).

486 Similarly, while the growth of $P$. oceanica decreases at higher temperatures (Fig. 2a),

487 given that in parallel urchin growth decreases (Fig. 3a), as does consumption (Fig. 5a)

488 and palatability is reduced (Fig. 5b), the impact of herbivory may still decrease or remain

489 unchanged for this species (Fig. 6a). In sharp contrast, the canopy-forming macroalga, $C$.

490 mediterranea is probably most at risk from increasing temperatures, once again as a result

491 of a suite of changes in mechanisms affecting plant-herbivore interactions. Thus, while it

492 reduces its growth in elevated temperature conditions (Fig. 2c), urchin consumption

493 remains high until $25{ }^{\circ} \mathrm{C}$ (Fig. 5e), while palatability does not decrease at the highest

494 temperatures (Fig. 5f). If anything, the strength of this algae-herbivore interaction is set

495 to increase with ocean warming (Fig. 6c). This is particularly worrying, given that of all

496 the systems we studied, benthic macroalgal systems are most prone to state shifts, often

497 precipitated by urchin overgrazing (Boada et al., 2017; Pinnegar et al., 2000).

499 In interpreting these results, it is essential to remember that there are several additional 500 mechanisms that we have not considered. Our laboratory experiments and the 
501 performance curves test the current tolerance limits of the species in question to changing 502 conditions. Of course, as temperatures change, it is quite possible for species to acclimate

503 within the limits of their phenotypic plasticity, or genetically adapt to increasing 504 temperatures by selection of the fittest genotypes (Lee et al., 2007). While most plants 505 show considerable capacity to adjust their photosynthetic traits to enhance their 506 performance, this ability varies considerably between species (Lee et al., 2007). 507 Consumers, in contrast, tend to be more sensitive to warming (Voigt et al., 2003). The 508 consumer $P$. lividus, however, is a thermal generalist that experiences a wide range of 509 environmental temperatures, ranging from 10 to $30^{\circ} \mathrm{C}$ (Boudouresque and Verlaque, 510 2001), and is potentially exposed to extremes of temperatures in shallow coastal bays.

511 How plants and animals acclimate or adapt to increasing temperatures will significantly 512 change performance optima and result in further changes in the plant-animal interaction.

513 As species are pushed to the edge of their tolerance limits, we should expect a host of 514 individual and population-level consequences that will also be critical to ecosystem 515 functioning (Bennett et al., 2015; Tylianakis et al., 2008). However, in a field experiment 516 using a thermal plume, Garthwin et al. (2014) showed that a meadow of the seagrass

517 Zostera muelleri that had been exposed to sustained higher temperatures for 30 years had

518 similar levels of growth and herbivory than un-impacted meadows nearby. Similarly, 519 Morelissen and Harley (2007) found that even though individual species may be 520 influenced by temperature, plant-herbivore interactions may not necessarily be. Other 521 studies, in contrast, have found that warming tends to increase interaction strength 522 between producers and consumers (O'Connor et al., 2009; Poore et al., 2013). Our 523 heuristic models help to explain why warming may or may not modify plant-herbivore 524 interaction strength by influencing some of the components of these interactions (see 525 rationale at the end of introduction). Moreover, our results show that the same amount of 
526 warming might have opposing effects on Mediterranean macrophyte-herbivore 527 interactions contingent on species specific thermal performance. We must apply caution

528 when interpreting our heuristic models (Fig. 6), given the low number of temperature 529 levels used in the plant growth experiments (see Fig. 2). As a sensitivity exercise, we 530 examined the effect of shifting the plants' thermal performance curves around their 531 optima, leaving the urchins' performance curves unchanged (see results in the 532 supplementary, Figs. 8-10). The sensitivity analysis confirmed the results observed in 533 Fig. 6, given that the changes to the resulting herbivore performance curves changed 534 minimally. In the future, however, we might have to introduce more actors into the 535 picture, as the sparid Sarpa salpa (L.) and the thermophilous black sea urchin Arabacia 536 lixula (L.) will also likely be affected by warming (Gianguzza et al., 2011; Privitera et al., 537 2011). Moreover, warming is already causing a host of tropical species, such as the 538 herbivorous rabbitfish (Siganus luridus and S. rivulatus), to migrate to temperate areas 539 (Vergés et al., 2014), altering local interactions and potentially precipitating algal barrens $540 \quad$ (Sala et al., 2011).

542 As far as we are aware, this is the first study to explicitly examine how warming mediates

543 key plant-animal interactions (that structure Mediterranean macrophyte communities in 544 this case) at this diversity of scales (from the behavioural, metabolic, to individual level).

545 Moreover, the inclusion of these responses in simple heuristic models demonstrates that 546 the complex effects of warming on plant-animal interactions are the result not merely of 547 their effect on each individual species' survival, but also of temperature changing a suite 548 of plant and animal responses (including palatability and potentially behaviour [not in 549 this case]) that are difficult to predict a priori. This can lead to unexpected results. 550 Ecological interactions have developed over evolutionary time scales and are the 
551 consequence of a dynamic interplay between each species attempting to adjust to 552 environmental changes as well as ensuring its own evolutionary success. Rapid 553 environmental changes are accelerating this dynamic process, stretching the ability of 554 species to cope with the rate of these changes. How these interactions play out in real555 world scenarios, where several species interact both directly and indirectly in a dizzyingly 556 complex network of interactions, is difficult to conceive, especially given that warming experiments generally assume that individual organisms that have been experimentally warmed in short-term experiments, will respond in a similar way as individuals whose ancestors have been exposed to the same level of warming over decades. In any case, our

560 results show that not all of these consequences are going to be negative, since some 561 species may be able to compensate for the effects of temperature, leaving the interaction 562 itself unchanged. Some structural species, like C. nodosa in the case of this study, may even emerge as clear winners in these scenarios. Much will depend on the plasticity and

564 adaptive capacity of the individual actors within the interaction to this change. It may be 565 useful to think of interactions themselves as having an inherent plasticity, adapting in a 566 coupled way to changing conditions. There will be limits to this joint plasticity, breaking 567 down either as its individual actors cross tolerance thresholds, or when the interaction 568 itself becomes too strong or too weak (see Fig. 6). Clearly, as human-induced rapid 569 environmental change continues apace, it is pushing us to investigate more carefully what 570 governs species interactions, in order to understand how they will respond to change.

571 Knowing what to expect of these ecosystems in the near future, may help us manage them

572 more effectively. We believe we can be moderately optimistic for Mediterranean seagrass communities given their expected unchanged or reduced herbivore pressure as warming continues. However, our study should serve as an early warning for Mediterranean

575 macroalgal communities, which are already subject to strong top-down control due to the 
576 loss of top-predators (Pinnegar et al., 2000), but which are likely to be subjected to even 577 higher herbivore pressure.

578

\section{Acknowledgments}

580 We would like to thank Mònica Vergés, Donatella Palomba, Ana Calvo, Lluís Casabona,

581 Sandra Muñoz, Elisabet Nebot and Irene Giralt for their help in setting up and following 582 the experiments in the lab. We thank Liliana Salvador for providing the Matlab script that 583 allowed us to perform the image analysis of sea urchin movements. We would also like 584 to thank Josep Pascual, observer from l'Estartit meteorological station, for kindly letting 585 us use his weekly seawater temperature time series; David Alonso for his help in 586 discussing the heuristic models, and two anonymous reviewers for their comments. The 587 Spanish Ministry of Science and Innovation funded this research (projects CMT2010588 22273-C02-01-02 and CMT2013-48027-C03-R) and supported JB (scholarship BES-

589 2011-043630). The Spanish National Research Council supported RA's visitorship 590 (CSIC-201330E062). TS was supported by an Australian Government Endeavour 591 Fellowship. JFP acknowledges financial support from the Welsh Government and Higher

592 Education Funding Council for Wales through the Sêr Cymru National Research Network 593 for Low Carbon, Energy and Environment. Support to FT was provided by the Ramón y 594 Cajal Programme (RYC-2011-08572). 
597 Allen, A.P., Gillooly, J.F., Brown, J.H., 2005. Linking the global carbon cycle to individual metabolism. Funct. Ecol. 19, 202-213. doi:10.1111/j.1365-2435.2005.00952.x

Angilletta, M.J., 2006. Estimating and comparing thermal performance curves. J. Therm. Biol. 31, 541-545. doi:10.1016/j.jtherbio.2006.06.002

Bakker, E.S., Wood, K.A., Pagès, J.F., Veen, G.F. (Ciska), Christianen, M.J.A., Santamaría, L., Nolet, B.A., Hilt, S., 2016. Herbivory on freshwater and marine macrophytes: A review and perspective. Aquat. Bot. 135, 18-36. doi:10.1016/j.aquabot.2016.04.008

Bale, J.S., Masters, G.J., Hodkinson, I.D., Awmack, C., Bezemer, T.M., Brown, V.K., Butterfield, J., Buse, A., Coulson, J.C., Farrar, J., Good, J.E.G., Harrington, R., Hartley, S., Jones, T.H., Lindroth, R.L., Press, M.C., Symrnioudis, I., Watt, A.D., Whittaker, J.B., 2002. Herbivory in global climate change research: Direct effects of rising temperature on insect herbivores. Glob. Chang. Biol. 8, 1-16.

Ballesteros, E., 1992. Els vegetals i la zonació litoral: especies, comunitats i factors que influeixen en la seva distribució. Institut d'Estudis Catalans (IEC), secció de Ciències Biològiques, Barcelona.

Bascompte, J., Jordano, P., Olesen, J.M., 2006. Asymmetric coevolutionary networks facilitate biodiversity maintenance. Science (80-. ). 312, 431-433.

Bates, D., Maechler, M., Bolker, B., Walker, S., Christensen, R.H.B., Singmann, H., Dai, B., Grothendieck, G., Green, P., 2017. lme4: Linear Mixed-Effects Models using “Eigen” and S4.

Bennett, S., Wernberg, T., Arackal Joy, B., de Bettignies, T., Campbell, A.H., 2015. Central and rear-edge populations can be equally vulnerable to warming. Nat. Commun. 6, 10280.

Boada, J., Arthur, R., Alonso, D., Pagès, J.F., Pessarrodona, A., Oliva, S., Ceccherelli, G., Piazzi, L., Romero, J., Alcoverro, T., 2017. Immanent conditions determine imminent collapses: nutrient regimes define the resilience of macroalgal communities. Proc. R. Soc. 
624 Boudouresque, C.F., Verlaque, M., 2001. Ecology of Paracentrotus lividus, in: Lawrence, J. (Ed.), Edible Sea-Urchins: Biology and Ecology. Elsevier publ., Amsterdam, pp. 177216.

Calenge, C., 2011. Analysis of Animal Movements in R : the adehabitatLT Package 1-54.

Cebrián, J., 1999. Patterns in the fate of production in plant communities. Am. Nat. 154, 449468.

630 Collard, M., Rastrick, S., Calosi, P., Demolder, Y., Dille, J., S, F.H., Hall-Spencer, J.M., Milazzo, M., Moulin, L., Widdicombe, S., Dehairs, F., Dubois, P., 2016. The impact of ocean acidification and warming on the skeletal mechanical properties of the sea urchin Paracentrotus lividus from laboratory and field observations. ICES J. Mar. Sci. 73, 727738. doi:10.1093/icesjms/fst176

Collins, M., Knutti, R., Arblaster, J., Dufresne, J.-L., Fichefet, T., Friedlingstein, P., Gao, X.,

Coma, R., Ribes, M., Serrano, E., Jiménez, E., Salat, J., Pascual, J., 2009. Global warmingenhanced stratification and mass mortality events in the Mediterranean. Proc. Natl. Acad. Gutowski, W.J., Johns, T., Krinner, G., Shongwe, M., Tebaldi, C., Weaver, A.J., Wehner, M., 2013. Long-term Climate Change: Projections, Commitments and Irreversibility, in: Climate Change 2013: The Physical Science Basis. Contribution of Working Group I to the Fifth Assessment Report of the Intergovernmental Panel on Climate Change. pp. 1029-1136. doi:10.1017/CBO9781107415324.024 J. a, Sala, O., Wolters, V., Wall, D., Winfree, R., Xenopoulos, M. a, 2011. Habitat Loss , Trophic Collapse, and the Decline of Ecosystem Services Published by : Ecological Society of America Stable URL : http://www.jstor.org/stable/20069174 . Ecology 87, $1915-1924$.

Fritz, R.S., Simms, E.L., 1992. Plant Resistance to Herbivores and Pathogens: Ecology, evolution and genetics. The University of Chicago Press. 
651 Gacia, E., Invers, O., Manzanera, M., Ballesteros, E., Romero, J., 2007. Impact of the brine 652 from a desalination plant on a shallow seagrass (Posidonia oceanica) meadow. Estuar. 653 Coast. Shelf Sci. 72, 579-590. doi:10.1016/j.ecss.2006.11.021

654 García, E., Clemente, S., López, C., McAlister, J.S., Hernández, J.C., 2015. Ocean warming 655 modulates the effects of limited food availability on Paracentrotus lividus larval development. Mar. Biol. 162, 1463-1472. doi:10.1007/s00227-015-2682-0

657 Garrabou, J., Coma, R., Bensoussan, N., Bally, M., Chevaldonné, P., Cigliano, M., Diaz, D., 658 Harmelin, J.G., Gambi, M.C., Kersting, D.K., Ledoux, J.B., Lejeusne, C., Linares, C., 659 Marschal, C., Pérez, T., Ribes, M., Romano, J.C., Serrano, E., Teixidó, N., Torrents, O., 660 Zabala, M., Zuberer, F., Cerrano, C., 2009. Mass mortality in Northwestern Mediterranean 661 rocky benthic communities: effects of the 2003 heat wave. Glob. Chang. Biol. 15, 1090662 1103. doi:10.1111/j.1365-2486.2008.01823.x

663 Garthwin, R.G., Poore, A.G.B., Vergés, A., 2014. Seagrass tolerance to herbivory under 664 increased ocean temperatures. Mar. Pollut. Bull. 83, 475-482.

665 doi:10.1016/j.marpolbul.2013.08.010

666 Gianguzza, P., Agnetta, D., Bonaviri, C., Di Trapani, F., Visconti, G., Gianguzza, F., Riggio, S., 667 2011. The rise of thermophilic sea urchins and the expansion of barren grounds in the 668 Mediterranean Sea. Chem. Ecol. 27, 129-134. doi:10.1080/02757540.2010.547484 669 Gibert, J.P., Chelini, M.C., Rosenthal, M.F., Delong, J.P., 2016. Crossing regimes of 670 temperature dependence in animal movement. Glob. Chang. Biol. 22, 1722-1736. doi: $10.1111 /$ gcb. 13245

672 Gutow, L., Petersen, I., Bartl, K., Huenerlage, K., 2016. Marine meso-herbivore consumption 673 scales faster with temperature than seaweed primary production. J. Exp. Mar. Bio. Ecol. 477, 80-85. doi:10.1016/j.jembe.2016.01.009

Hereu, B., 2005. Movement patterns of the sea urchin Paracentrotus lividus in a marine reserve and an unprotected area in the NW Mediterranean. Mar. Ecol. Evol. Perspect. 26, 54-62.

677 Hernán, G., Ortega, M.J., Gándara, A.M., Castejón, I., Terrados, J., Tomas, F., 2017. Future 678 warmer seas: Increased stress and susceptibility to grazing in seedlings of a marine 
680 Hernán, G., Ramajo, L., Basso, L., Delgado, A., Terrados, J., Duarte, C.M., Tomas, F., 2016.

681 Seagrass (Posidonia oceanica) seedlings in a high-CO2 world: from physiology to

682 herbivory. Sci. Rep. 6, 38017. doi:10.1038/srep38017

683 Hurlbert, S.H., 1984. Pseudoreplication and the Design of Ecological Field Experiments. Ecol. $684 \quad$ Monogr. 54, 187-211.

685 IPCC, 2013. Climate change 2013: The physical science basis. Contribution of Working Group 686 I to the Fourth Assessment Report to the Intergovernmental Panel on Climate Change.

687 Ives, A.R., Carpenter, S.R., 2007. Stability and diversity of ecosystems. Science 317, 58-62. 688 doi:10.1126/science. 1133258

689 Janssens, L., Van Dievel, M., Stoks, R., 2015. Warming reinforces nonconsumptive predator 690 effects on prey growth, physiology, and body stoichiometry. Ecology 96, 3270-3280. doi:10.1890/15-0030.1

692 Jorda, G., Marbà, N., Duarte, C.M., 2012. Mediterranean seagrass vulnerable to regional climate 693 warming. Nat. Clim. Chang. advance on.

694 doi:http://www.nature.com/nclimate/journal/vaop/ncurrent/abs/nclimate1533.html\#supple 695 mentary-information

696 Kirtman, B., Power, S.B., Adedoyin, J.A., Boer, G.J., Bojariu, R., Camilloni, I., Doblas-Reyes, F.J., Fiore, A.M., Kimoto, M., Meehl, G.A., Prather, M., Sarr, A., Schär, C., Sutton, R.,

Kordas, R.L., Harley, C.D.G., O’Connor, M.I., 2011. Community ecology in a warming world: The influence of temperature on interspecific interactions in marine systems. J. Exp. Mar. Bio. Ecol. 400, 218-226. doi:Export Date 24 July 2013 
Lemoine, N.P., Burkepile, D.E., 2012. Temperature-induced mismatches between consumption and metabolism reduce consumer fitness. Ecology 93, 2483-2489. doi:10.1890/12-0375.1

Marbà, N., Duarte, C.M., 2010. Mediterranean warming triggers seagrass (Posidonia oceanica) shoot mortality. Glob. Chang. Biol. 16, 2366-2375. doi:10.1111/j.13652486.2009.02130.x

McCann, K., 2007. Protecting biostructure. Nature 446, 29. doi:10.1038/446029a

Morelissen, B., Harley, C.D.G., 2007. The effects of temperature on producers, consumers, and plant-herbivore interactions in an intertidal community. J. Exp. Mar. Bio. Ecol. 348, 162173. doi:10.1016/j.jembe.2007.04.006

Nemani, R.R., Keeling, C.D., Hashimoto, H., Jolly, W.M., Piper, S.C., Tucker, C.J., Myneni, R.B., Running, S.W., 2003. Climate-driven increases in global terrestrial net primary production from 1982 to 1999 . Science 300, 1560-3. doi:10.1126/science. 1082750

O’Connor, M.I., 2009. Warming strengthens an herbivore-plant interaction. Ecology 90, 388398. doi:Export Date 24 July 2013

O’Connor, M.I., Gilbert, B., Brown, C.J., 2011. Theoretical Predictions for How Temperature Affects the Dynamics of Interacting Herbivores and Plants. Am. Nat. 178, 626-638. doi: $10.1086 / 662171$

O’Connor, M.I., Piehler, M.F., Leech, D.M., Anton, A., Bruno, J.F., 2009. Warming and resource availability shift food web structure and metabolism. PLoS Biol. 7. doi:Export Date 24 July 2013Art. No. e1000178

Padilla-Gamiño, J.L., Carpenter, R.C., 2007. Thermal ecophysiology of Laurencia pacifica and Laurencia nidifica (Ceramiales, Rhodophyta) from tropical and warm-temperate regions. J. Phycol. 43, 686-692. doi:10.1111/j.1529-8817.2007.00362.x

Pagès, J.F., 2013. A behavioural seascape ecology approach to macrophyte herbivory. Universitat de Barcelona. 
736 Pagès, J.F., Pérez, M., Romero, J., 2010. Sensitivity of the seagrass Cymodocea nodosa to 737 hypersaline conditions: A microcosm approach. J. Exp. Mar. Bio. Ecol. 386, 34-38. 738 Parmesan, C., 2006. Ecological and Evolutionary Responses to Recent Climate Change. Annu. Rev. Ecol. Evol. Syst. 37, 637-669. doi:10.2307/annurev.ecolsys.37.091305.30000024

Peñuelas, J., Staudt, M., 2010. BVOCs and global change. Trends Plant Sci. 15, 133-144. doi:10.1016/j.tplants.2009.12.005

Pérez, M., Romero, J., 1994. Growth dynamics, production and nutrient status of the seagrass Cymodocea nodosa in a Mediterranean semi-estuarine environment. Mar. Ecol. Della Stn. Zool. Di Napoli I 15, 51-64.

Pérez, M., Romero, J., 1992. Photosynthetic response to light and temperature of the seagrass Cymodocea nodosa and the prediction of its seasonality. Aquat. Bot. 43, 51-62.

Pinnegar, J.K., Polunin, N.V.C., Francour, P., Badalamenti, F., Chemello, R., Harmelin-Vivien, M.L., Hereu, B., Milazzo, M., Zabala, M., D’Anna, G., Pipitone, C., 2000. Trophic

Polis, G.A., 1999. Why are parts of the world green? Multiple factors control productivity and the distribution of biomass. Oikos $86,3-15$.

Poore, A.G.B., Graba-Landry, A., Favret, M., Sheppard Brennand, H., Byrne, M., Dworjanyn,

Post, E., Pedersen, C., 2008. Opposing plant community responses to warming with and without herbivores. Proc. Natl. Acad. Sci. U. S. A. 105, 12353-12358.

Prado, P., Tomas, F., Alcoverro, T., Romero, J., 2007. Extensive direct measurements of Posidonia oceanica defoliation confirm the importance of herbivory in temperate seagrass meadows. Mar. Ecol. Ser. 340, 63-71.

761 Privitera, D., Noli, M., Falugi, C., Chiantore, M., 2011. Benthic assemblages and temperature effects on Paracentrotus lividus and Arbacia lixula larvae and settlement. J. Exp. Mar. Bio. 
Ecol. 407, 6-11. doi:10.1016/j.jembe.2011.06.030

Ruiz, J.M., Perez, M., Romero, J., 2001. Effects of Fish Farm Loadings on Seagrass ( Posidonia oceanica ) Distribution, Growth and Photosynthesis. Mar. Pollut. Bull. 42.

Sala, E., Kizilkaya, Z., Yildirim, D., Ballesteros, E., 2011. Alien marine fishes deplete algal biomass in the Eastern Mediterranean. PLoS One 6.

Sala, O.E., Chapin III, F.S., Armesto, J.J., Berlow, E., Bloomfield, J., Dirzo, R., HuberSanwald, E., Huenneke, L.F., Jackson, R.B., Kinzig, A., Leemans, R., Lodge, D.M.,

Sanmartí, N., Saiz, L., Llagostera, I., Pérez, M., Romero, J., 2014. Tolerance responses to simulated herbivory in the seagrass Cymodocea nodosa. Mar. Ecol. Prog. Ser. 517, 159-

Sentis, A., Morisson, J., Boukal, D.S., 2015. Thermal acclimation modulates the impacts of temperature and enrichment on trophic interaction strengths and population dynamics.

Seuront, L., Stanley, H.E., 2014. Anomalous diffusion and multifractality enhance mating encounters in the ocean. Proc. Natl. Acad. Sci. U. S. A. 111, 2206-11. doi:10.1073/pnas.1322363111

Somero, G.N., 2012. The Physiology of Global Change: Linking Patterns to Mechanisms. Annu. Rev. Mar. Sci. Vol 4 4, 39-61. doi:DOI 10.1146/annurev-marine-120710-100935

Strauss, S.Y., Agrawal, A.A., 1999. The ecology and evolution of plant tolerance to herbivory. Trends Ecol. Evol. 14, 179-185.

Suttle, K.B., Thomsen, M.A., Power, M.E., 2007. Species Interactions Reverse Grassland Responses to Changing Climate. Science (80-. ). 315, 640-642.

Tomas, F., Martínez-Crego, B., Hernán, G., Santos, R., 2015. Responses of seagrass to anthropogenic and natural disturbances do not equally translate to its consumers. Glob. Chang. Biol. 21, 4021-4030. doi:10.1111/gcb.13024 

herbivory pressure on the temperate seagrass Posidonia oceanica. Mar. Ecol. Ser. 301, 95107.

Tomasello, A., Di Maida, G., Calvo, S., Pirrotta, M., Borra, M., Procaccini, G., 2009. Seagrass meadows at the extreme of environmental tolerance: The case of Posidonia oceanica in a semi-enclosed coastal lagoon. Mar. Ecol. 30, 288-300. doi:10.1111/j.14390485.2009.00285.x

Tylianakis, J.M., Didham, R.K., Bascompte, J., Wardle, D.A., 2008. Global change and species interactions in terrestrial ecosystems. Ecol. Lett. 11, 1351-1363.

Tylianakis, J.M., Tscharntke, T., Lewis, O.T., 2007. Habitat modification alters the structure of tropical host-parasitoid food webs. Nature 445, 202-205.

Van De Velde, H., Nijs, I., Bonte, D., 2016. Warming affects different components of plantherbivore interaction in a simplified community but not net interaction strength. Oikos 285-295. doi:10.1111/oik.03415

Vergés, A., Becerro, M. a, Alcoverro, T., Romero, J., 2007b. Variation in multiple traits of vegetative and reproductive seagrass tissues influences plant-herbivore interactions. Oecologia 151, 675-86. doi:10.1007/s00442-006-0606-x A. a., Spiegel, D., Sala, E., 2014. Tropical rabbitfish and the deforestation of a warming

817 Voigt, W., Perner, J., Davis, A.J., Eggers, T., Schumacher, J., Bährmann, R., Fabian, B., 818 Heinrich, W., Köhler, G., Lichter, D., Marstaller, R., Sander, F.W., 2003. Trophic Levels 
820 Way, D.A., Oren, R., 2010. Differential responses to changes in growth temperature between 821 trees from different functional groups and biomes: a review and synthesis of data. Tree $822 \quad$ Physiol. 30, 669-688. doi:10.1093/treephys/tpq015

823 Welsh, J., Bellwood, D.R., 2012. How far do schools of roving herbivores rove? A case study 824 using Scarus rivulatus. Coral Reefs in press. doi:10.1007/s00338-012-0922-z

825 Wernberg, T., Smale, D.A., Thomsen, M.S., 2012. A decade of climate change experiments on 826 marine organisms: Procedures, patterns and problems. Glob. Chang. Biol. 18, 1491-1498. 827 doi:10.1111/j.1365-2486.2012.02656.x

828 Yerramilli, D., Johnsen, S., 2010. Spatial vision in the purple sea urchin Strongylocentrotus 829 purpuratus (Echinoidea). J. Exp. Biol. 213, 249-255.

830 Zuur, A.F., Ieno, E.N., Walker, N.J., Saveliev, A.A., Smith, G.H., 2009. Mixed Effects Models 831 and Extensions in Ecology with R. Springer Science+Business Media, New York. 


\section{Figure legends}

835 Fig. 1. Conceptual model of the potential outcomes of plant-animal interactions in a warming

836 Mediterranean. The arrow above the dashed vertical lines show the direction of warming. (a)

837 When both plant and herbivore thermal performance curves are of similar shape and display the

838 same optimal temperature, warming will not produce any changes to herbivore pressure ${ }^{1}$. (b) If

839 plant performs better at warmer temperatures compared to the herbivore, herbivore pressure ${ }^{1}$ will

840 decrease with warming. (c) In contrast, herbivore pressure ${ }^{1}$ will increase with warming, if the

841 herbivore performs better at warmer temperatures compared to the plant. See the supplementary

842 for more information on the shape of these theoretical curves.

$843{ }^{1}$ Here, we conceptually define herbivore pressure as the result of dividing herbivore performance by plant performance. 844

a

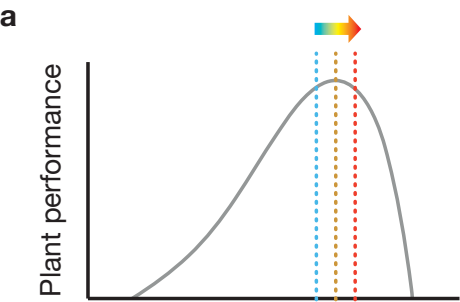

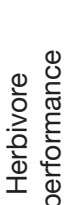
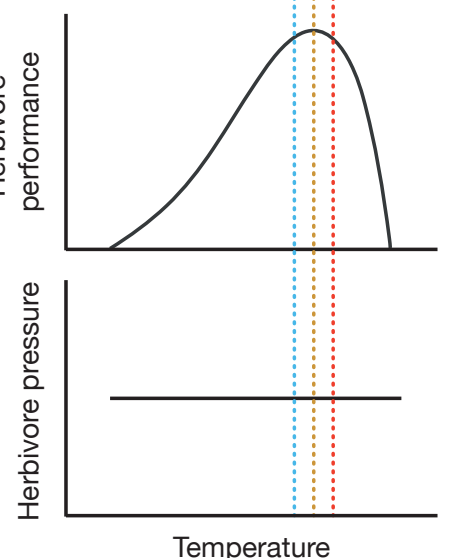

b
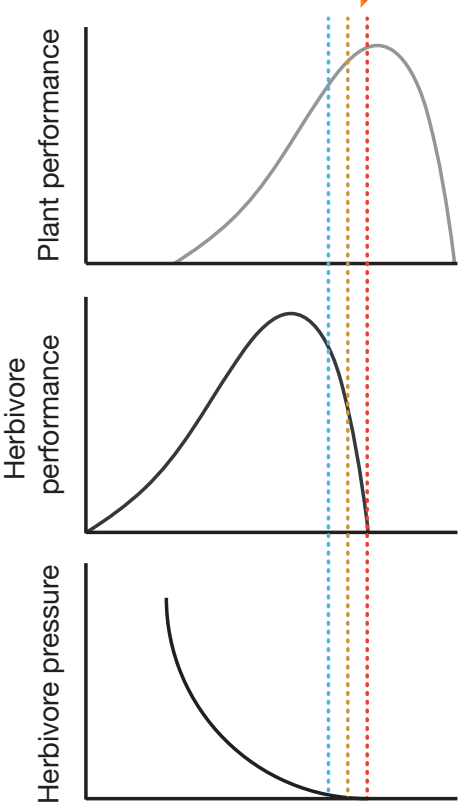

Temperature
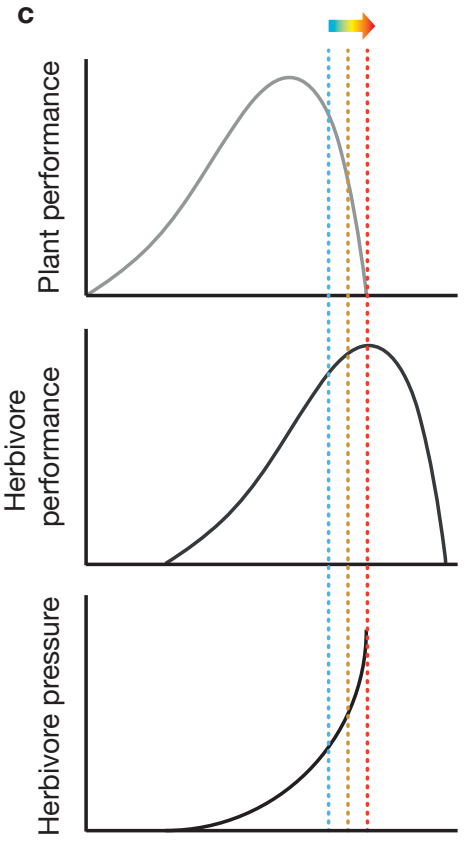

Temperature 
847 Fig. 2. Plant growth at different incubating temperatures. (a) Posidonia oceanica seagrass, (b)

848 Cymodocea nodosa seagrass, (c) Cystoseira mediterranea macroalgae. Asterisks denote 849 significant differences. Significance codes $\mathrm{p}<0.001^{\text {' } * * * ’}, \mathrm{p}<0.05^{\text {'**' }}$.

850
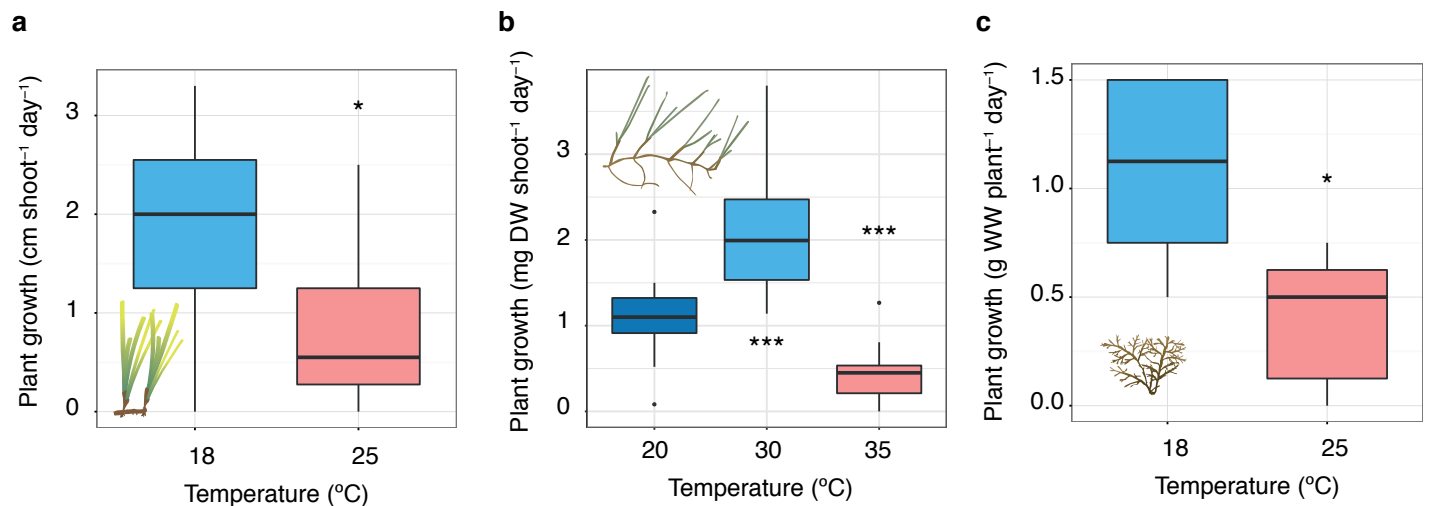

851

852 
853 Fig. 3. Sea urchin thermal performance curves (a) for growth and (b) respiration rates. Solid lines

854 correspond to the predictions of a linear model applied to the data sets using the quadratic term

855 of temperature as a predictor, hence the parabolic shape of the curve. Shaded areas define the

$85695 \%$ confidence intervals around fitted values. Sea urchin size significantly affected both growth

857 and respiration curves as well (see Fig. S1 from the supplementary).
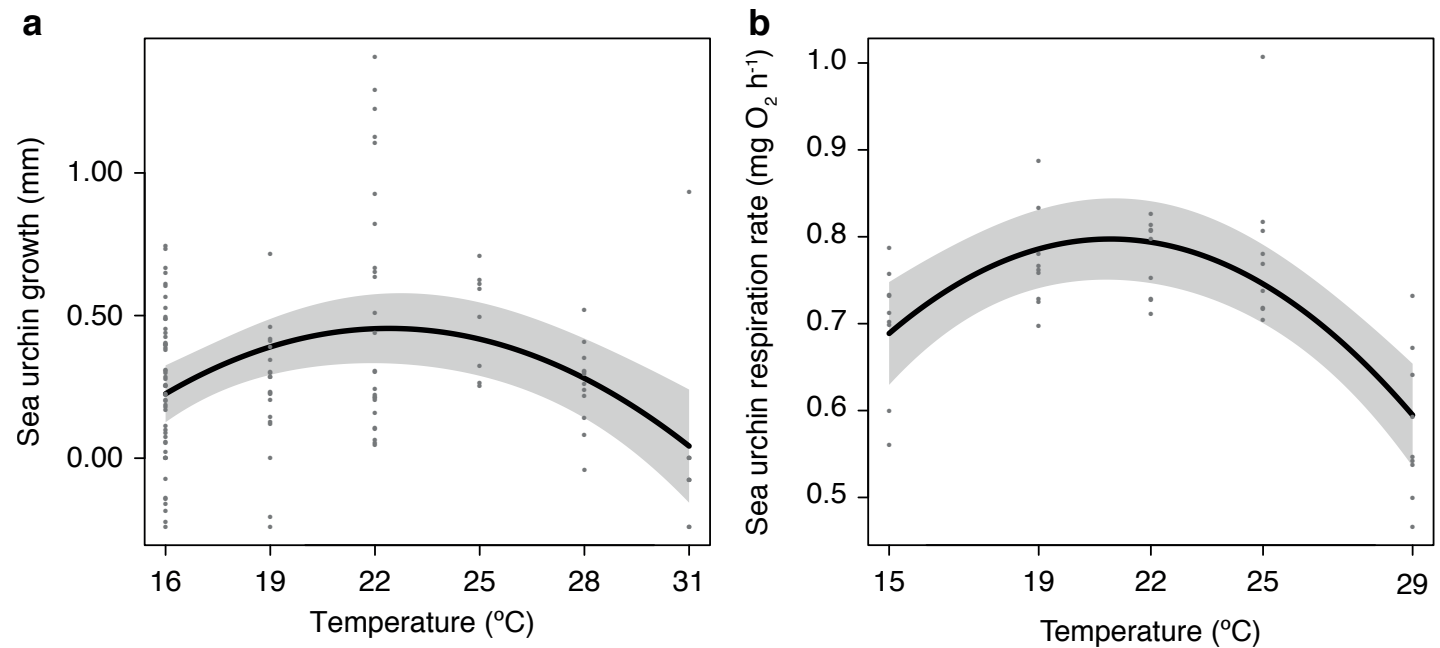

858

859

860 
861 Fig. 4. Sea urchin movement behaviour at cool and warm water temperatures. (a) Temperature

862 did not affect the tortuosity of sea urchin trajectories, (b) nor their mean speed. (c) The analysis

863 of sea urchin trajectories at different scales (see methods) did not find any differences between

864 the trajectories of urchins wandering in cool (blue solid line) or warm (red solid line) conditions.

865 The dotted line denotes a ballistic trajectory, while the dashed line represents Brownian motion.
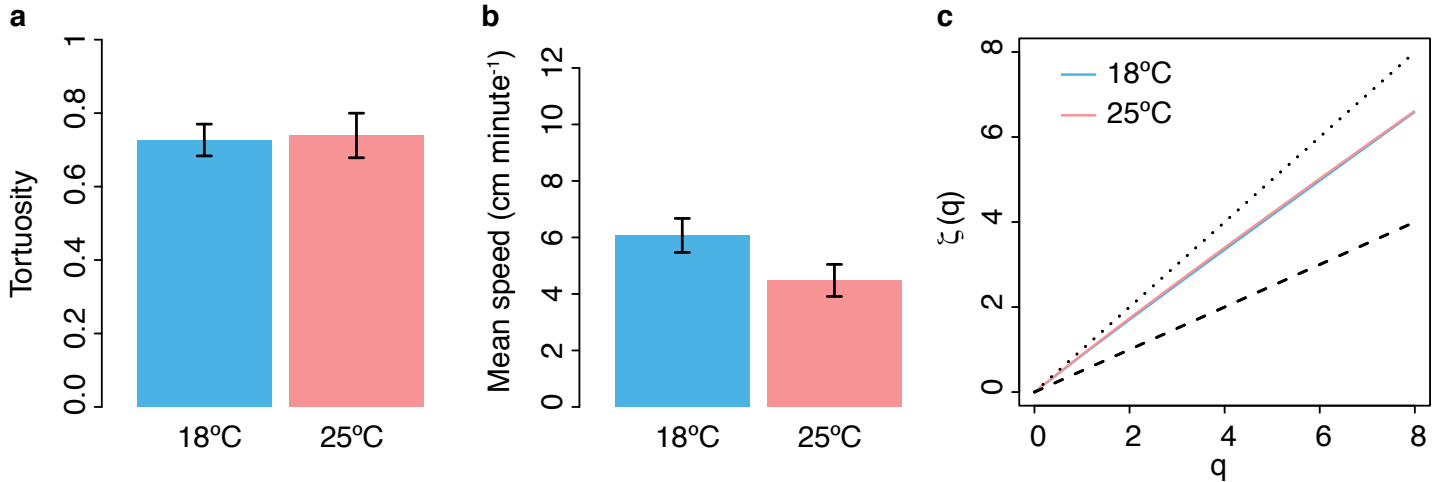

866

867

868 
869 Fig. 5. Sea urchin consumption rate at increasing temperatures and sea urchin choice of plants

870 incubated at cool and warm temperatures. (a, b) correspond to the seagrass Posidonia oceanica,

871 (c, d) to the seagrass Cymodocea nodosa, and (e, f) to the macroalgae Cystoseira mediterranea.

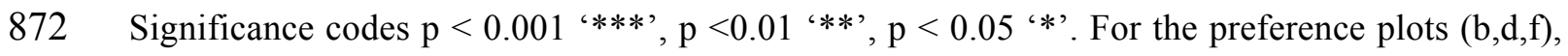

873 effects are significant $(\mathrm{P} \leq 0.05)$ where confidence intervals do not intercept 0 .

a

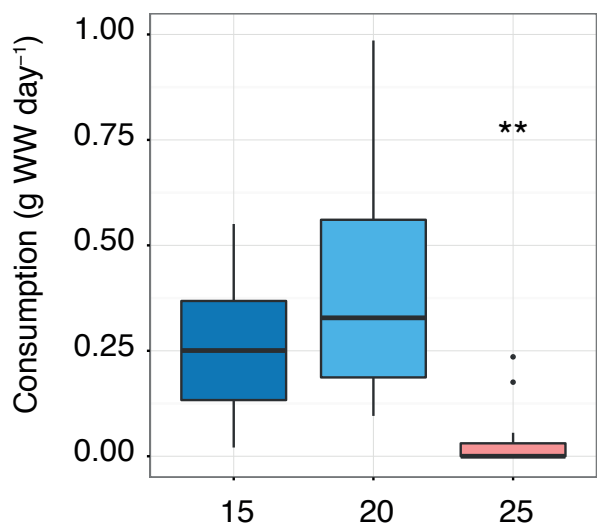

Aquarium temperature $\left({ }^{\circ} \mathrm{C}\right)$

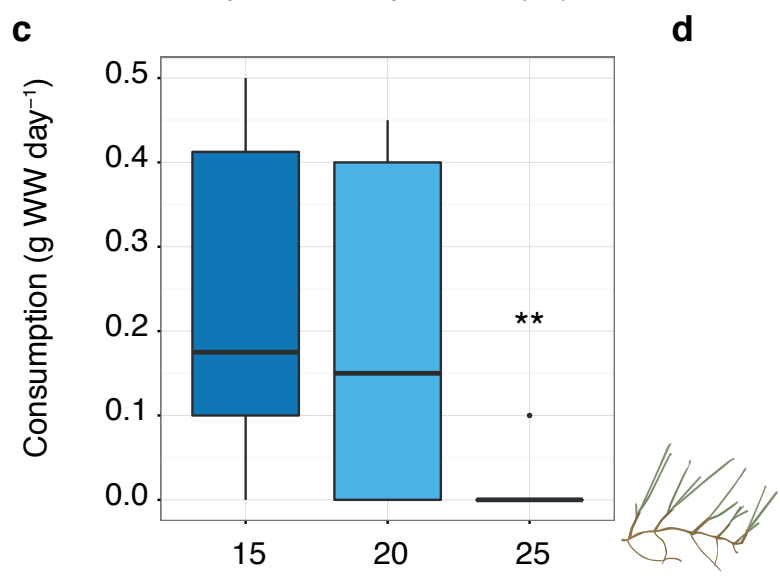

Aquarium temperature $\left({ }^{\circ} \mathrm{C}\right)$
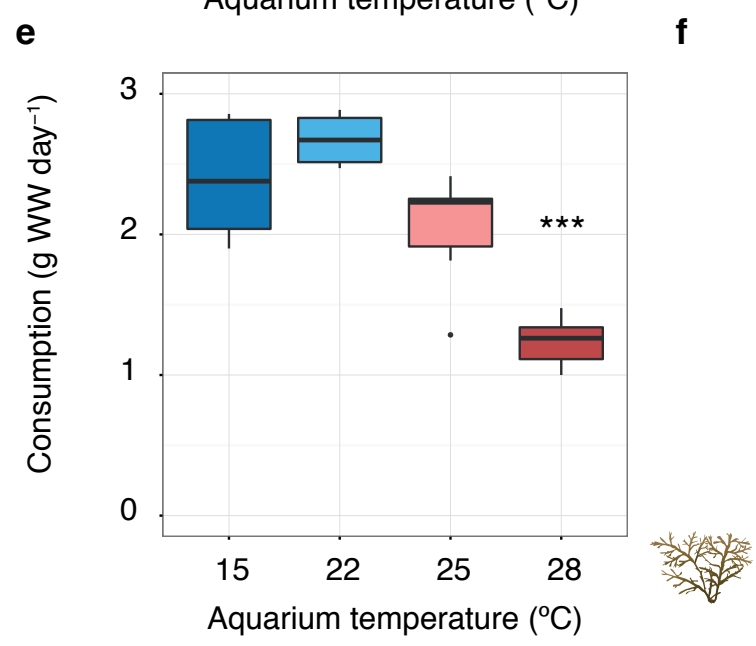

b
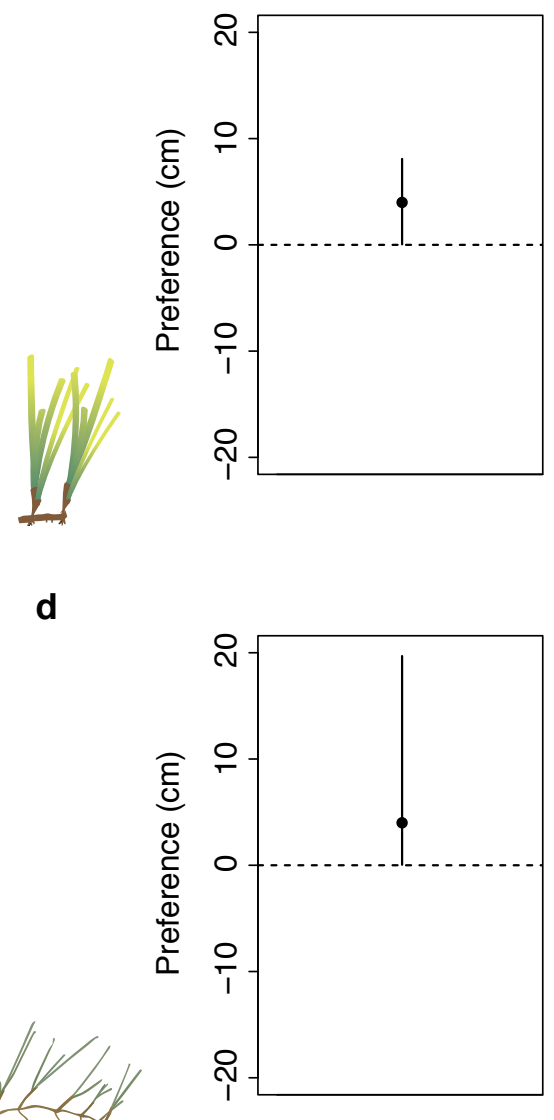

f

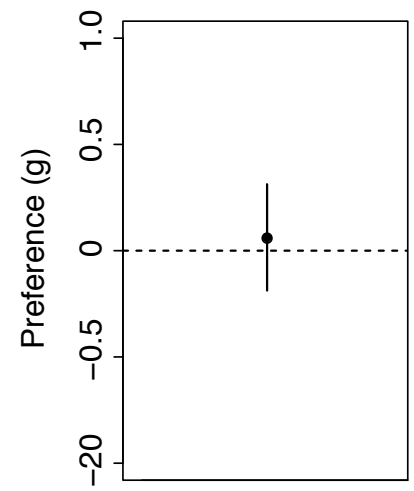


876 Fig. 6. Conceptual model of the outcomes of plant-animal interactions in a warming

877 Mediterranean. The arrow above the dashed vertical lines show the direction of warming. (a) We

878 expect herbivore pressure on Posidonia oceanica seagrass to keep unchanged with warming,

879 given that both the sea urchin and the seagrass display similar optimal temperatures of

880 performance; however, sea urchins' feeding rates plunge when offered $P$. oceanica seagrass

881 leaves from plants incubated at warm temperatures, hence the decrease in herbivore pressure

882 when warming increases (from the blue to the red dotted lines). (b) We expect the herbivore

883 pressure between urchins and the seagrass Cymodocea nodosa to decrease with warming given

884 the warmer optimal temperature of performance of the seagrass compared to the herbivore. The

885 herbivore pressure curve is expected to be especially steep at higher temperatures, given the lower

886 feeding rates of urchins when offered plants incubated at warm temperatures. (c) We expect the

887 herbivore pressure between the macroalga Cystoseira mediterranea and the sea urchin to increase

888 with warming, given the low performance of the macroalga at warm temperatures, while sea

889 urchins still display high feeding rates (see also Fig. 5). See methods and supplementary materials

890 for more information on the shape of these curves.

891
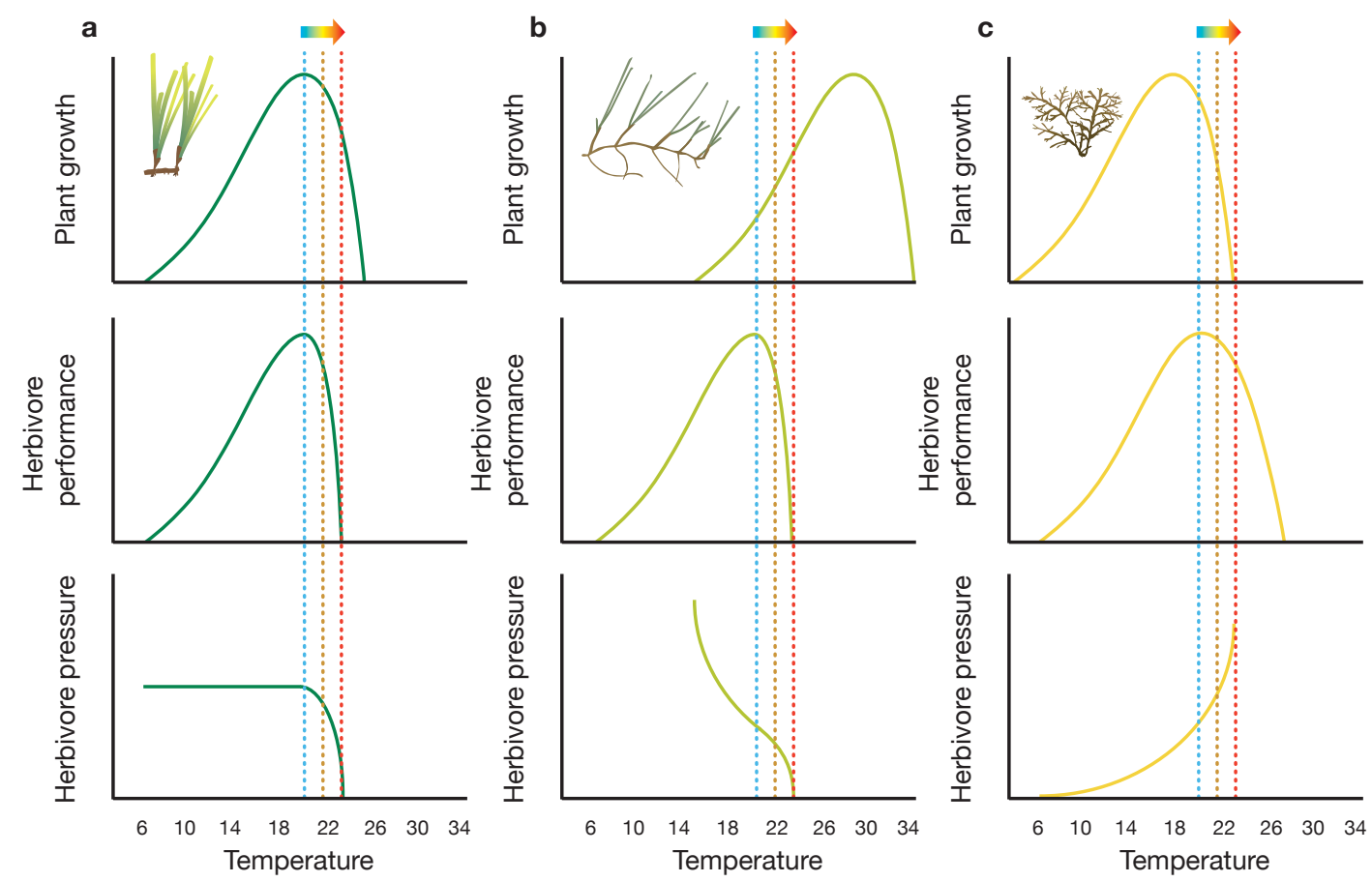

892 
Table 1. Summary of the different analyses performed. Model: type of model used in R (either linear [lm()/lme()], generalized linear with Poisson 894 distribution [glmer()], generalized linear with negative binomial distribution [glmer.nb()] or non-parametric Kruskal-Wallis [kruskal.test()]).

895 Random: type of random effects introduced into the model. Resp. Transf.: Type of transformation applied to the response variable. Df: Degrees of

896 freedom. Statistic: Depending on the model used the statistic used was Fisher's F, Chi-squared, or the Kruskal-wallis.

897 Significance codes $\mathrm{p}<0.001^{\text {'**** }}{ }^{*}, \mathrm{p}<0.01^{\text {'**' }}, \mathrm{p}<0.05^{\text {'*’ }}, \mathrm{p}>0.05^{\text {' }}$.

\begin{tabular}{|c|c|c|c|c|}
\hline Response variable & Model & Random & Resp. Transf. & Effect \\
\hline P. oceanica growth & Linear & - & - & $\begin{array}{l}\text { Temperature } \\
\text { Residuals }\end{array}$ \\
\hline C. nodosa growth & Linear & 1|Aquarium & $\operatorname{sqrt}(x)$ & Temperature \\
\hline $\begin{array}{l}\text { C. mediterranea } \\
\text { growth }\end{array}$ & Linear & - & - & $\begin{array}{l}\text { Temperature } \\
\text { Residuals }\end{array}$ \\
\hline Sea urchin growth & Linear & - & - & $\begin{array}{l}\text { Temperature } \\
\text { I(Temperature }{ }^{\wedge} 2 \text { ) } \\
\text { Size class } \\
\text { Residuals }\end{array}$ \\
\hline Sea urchin respiration & Linear & - & - & $\begin{array}{l}\text { Temperature } \\
\text { I(Temperature }{ }^{\wedge} 2 \text { ) } \\
\text { Size class } \\
\text { Residuals }\end{array}$ \\
\hline $\begin{array}{l}\text { P. oceanica } \\
\text { consumption }\end{array}$ & glm Poisson & 1|Aquarium & $\operatorname{round}(\mathrm{x} * 100)$ & $\begin{array}{l}\text { Temperature } \\
\text { Size class }\end{array}$ \\
\hline
\end{tabular}

$\begin{array}{llll}\begin{array}{l}\text { Sum squares } \\ 6.53\end{array} & \begin{array}{l}\text { Df } \\ 1\end{array} & \begin{array}{l}\text { Statistic } \\ 7.55\end{array} & \begin{array}{l}\text { P-value } \\ 0.010 *\end{array} \\ - & 28 & & \\ & & & \\ 1.14 & 2 & 21.12 & 2.610^{-5} * * * \\ 1.22 & 1 & 7.48 & 0.026^{*} \\ 1.70 & 8 & & \\ 1.74 & 1 & 18.89 & 2.910^{-5} * * * \\ 1.21 & 1 & 19.33 & 2.410^{-5} * * * \\ 10.99 & 2 & 6.74 & 0.002 * * \\ 0.15 & 122 & & \\ 0.17 & 1 & 36.48 & 4.610^{-7} * * * \\ 2.62 & 1 & 41.69 & 1.210^{-7} * * * \\ 0.16 & 2 & 319.38 & <210^{-16 * *} \\ - & 39 & & \\ - & 2 & 32.28 & 9.810^{-8} * * * \\ & 1 & 11.48 & 0.0007 * * *\end{array}$




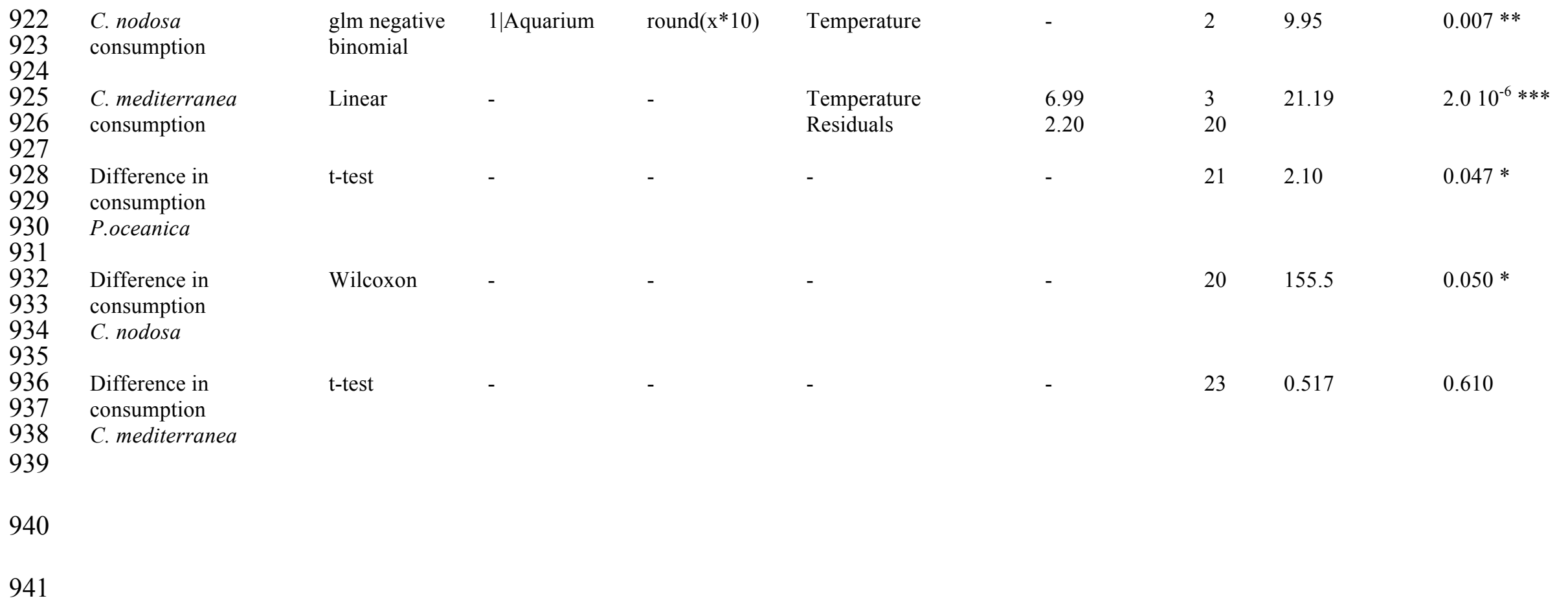

